\title{
КУЛЬТУРОЛОГИЧЕСКИЙ АСПЕКТ БРИТАНСКИХ ФАМИЛИЙ
}

\section{CULTURAL ASPECT OF BRITISH SURNAMES}

T. Golikova

Summary: The article introduces the reader to British surnames. It explains when and how surnames appeared in Great Britain. Noble and common surnames are compared, as well as English, Scottish, Irish and Welsh surnames. The origin of famous British surnames is discussed, as well as interesting surnames of Great Britain.

Keywords: cultural linguistics, culturally significant, background knowledge, family names, noble surnames, common surnames, British cultural space. $\square$ ель данной статьи - поиск ответа на вопрос, какую информацию о британской культуре несут фамилии.

Фамилии - это памятник нашим предкам. В России первые фамилии появились в XIII веке [1]. Однако большинство российских жителей получили фамилии лишь 600 лет спустя, после отмены крепостного права [там же]. Россия была огромной крестьянской страной, в которой большинство населения составляли крепостные. После отмены крепостного права крестьянам выдали паспорта. Это было сделано, в частности, для того, чтобы учитывать военнообязанных [5]. И тогда стали широко распространяться фамилии. Чуть позже провели перепись населения.

А когда и почему стали давать фамилии в Великобритании?

Уже в XI веке в Великобритании начался процесс принятия наследственных фамильных имен [7]. Согласно основной версии, фамилии были единственным способом идентифицировать людей в стране в тот период. В XI-XII веках большинство мужского населения Великобритании звали John, William, Ralph, Robert и Richard. Отчеств у англичан не было. Поэтому людям стали давать фамилии. Сначала давали фамилии знатным людям. А позже, в XVII веке, фамилии имели уже все слои британского общества.

На какие группы делятся английские фамилии?

Прежде всего, они бывают знатными и простыми.

В Великобритании существует около 200 дворян-
Голикова Татьяна Олеговна

К.филол.н., доцент, Российская академия народного хозяйства и государственной службы при Президенте Российской федерации - РАНХиГС, Москва tatianagolikova73@yandex.ru

Аннотация: Статья знакомит читателя с британскими фамилиями. Рассказывается, когда и почему появились фамилии в Великобритании. Сравниваются знатные и простые фамилии, а также собственно английские, шотландские, ирландские и валлийские фамилии. Рассматривается происхождение известных британских фамилий, а также интересные фамилии Великобритании.

Ключевые слова: лингвокультурология, культурно значимый, фоновые знания, фамильные имена, знатные фамилии, простые фамилии, англоязычное культурное пространство.

ских семей: Acton Family, Baden-Powell family, Capell family, De Clare family, Eden family, Fairfax family, Gage family, Harrington family, Keppel family, Lambdon family, Maugham family, Noel family, Oliver family, Parker family, Ridley family, Sainsbury family, Spencer Churchill family, Viller family и многие другие [11]. Все они существуют с древности и поныне. Считается также, что показателем благородной фамилии служит формант -е на конце слова, например Duncombe family, DiEste family, Fane family, Gore family, Granville family, Hope family, Neville family, Wilde family и др.

Фамилии простых людей - это Smith, Jones, Williams, Taylor, Davies, Brown, Willson, Evans, Thomas, Johnson, Roberts, Walker, Wright, Robinson, Thompson, White, Edwards, Green, Lewis, Wood, Harris, Martin, Jackson и другие [10]. Они очень широко распространены. Многие из них оканчиваются на форманты -son или - s, которые произошли от древнеанглийского sunu (сын).

Во-вторых, существуют фамилии собственно английские, ирландские, шотландские, валлийские.

Традиционно перед фамилией в Ирландии ставилась приставка O (или более древняя Ua) или Mac (Mak). Фамилии с приставкой Мас появились от обычая ирландцев называть сына, используя имя его отца (William Mac Gregory). Приставка "о" означает "оf". Часто ирландцы брали фамилии по месту, где они жили. Тут использовались названия рек, лесов, гор, холмов. Например, фамилия О'Kerry означает принадлежность к графству Керри в Ирландии.

Также часто фамилии в Ирландии (как и далеко не только в ней) происходят от личных качеств ее первых 
носителей: храбрости, доброты, мудрости и т.п. [4]. Например, О'Брайен (O’Brien) - высокий, благородный; О'Доерти (O'Doherty) - вредный; О'Кэррол (O'Carrol) человек, проявляющий доблесть в бою; О'Коннелл (O'Connell) - обладающий силой волка; О'Фаррелл (O'Farrell) - доблестный [4].

Самый распространенный элемент в шотландских гаэльских фамилиях - это элемент Мас (Мс). Наприmep, Mac a Bllaird, Mac a Bhiccair, Mac a Breatnaich, Mac a Chananaich, Mac a Phi, Mac an Aba [6].

Валлийские фамилии интересны тем, что изначально они были отчествами. При крещении имя человека связывали через ap, ab (сын) или ferch (дочь). Например, Эван сын Мартина был известен как Evan ab Martin. Эта система пришла в упадок к позднему Средневековью. На смену отчествам пришли фиксированные фамилии [2]. Валлийских фамилий в английском языке не так много, однако, они частотны. Типичные валлийские фамилии - Evans, Jones, Williams, Davis, Thomas. Валлийские фамилии часто восходят к древним валлийским отчествам и оканчиваются на формант $-s$.

Собственно английских фамилий в Великобритании гораздо больше. Чтобы их описать, был проанализирован Лингвокультурологический словарь английских фамилий С.И. Гарагули. Анализ словаря показывает, что фамилии в Англии, как и в Шотландии, Уэльсе, Ирландии давались по именам, по географическим названиям, по месту жительства, по занятиям, а также по внешности, по чертам характера, по прозвищам.

Наибольшее количество фамилий в словаре происходят от имен: Adam, Adams, Edison, Gerry, Gibbson, Gilbert, Gunter, Henry, Hobson, Jackson, James, Jefferson, Johnson, Martin и др.

В этой группе фамилий выделяется часть, имеющая библейское происхождение. Большое количество фамилий восходит к библейским именам Adam, David, Andrew, Nicholas и к имени Christian (Adam, Adams, Anderson, Davy, Collins). Также к библейским относится фамилия Eliot, происходящая «от уменьшительно-ласкательного Elle + суффикс ott, старофранцузской формы мужского рода Elins, которое, в свою очередь, представляет собой греческий вариант библейского имени Ellyahu - Yahweh is God - Иегова - бог мой» [3. с.81].

Фамилии, восходящие к библейскому имени David, обнаружены и среди валлийских (Dewey, фамилия известна с XIV века), и среди шотландских фамилий (Davies, Davis).

Думается, наличие фамилий, восходящих к библей- ским именам, говорит о присутствии христианских концептов в картине мира англичан, валлийцев, шотландцев.

Еще одна группа собственно английских фамилий связана с местностью: Crommwell, Disney Ford, Gainsborough, Garrick, Gladstone, Graham, Hamilton, Hoyle, Irwin, Lunn, Lynch.

И, наконец, еще одна большая группа собственно английских фамилий связана с занятиями: сельским хозяйством (Bacon, Byron, Hogarth, Bessemer, Colt), промышленностью (Bowdler), ремеслами (Fowler, Haggard, Hansard, Hood, Smith, Taylor, Thatcher), государственной службой (Bailey).

К прозвищам по занятиям восходят две культурнозначимые фамилии - Byron и Chaplin. Интересно посмотреть на их происхождение.

Фамилия Byron «восходит к древнеанглийскому нарицательному существительному byrum (дат. п., мн. ч. от byre - byre, barn, cowshed (хлев, коровник). Так называли того, кто был скотоводом или работником по уходу за животными. Это прозвище могло содержать также указание на место жительства основателя фамилии æt dæm byrum - at the byre or cowshed, - недалеко от хлева или коровника» [3. с.51]. Увековечил эту фамилию великий поэт Джордж Гордон Байрон.

Фамилия Chaplin «принадлежала представителям духовенства, и ее давали священнику, состоявшему при капелле как помощнику приходского священника. Данная фамилия восходит к старофранцузскому нарицательному существительному chapelain (capelain) [3. c.53].» Ee увековечил великий английский и американский актер Чарльз Спенсер Чаплин.

Английские фамилии описывают внешность человека. Например, фамилия Brown (смуглый), очевидно, восходит к прозвищу по цвету глаз, волос, кожи его носителя. Фамилия Bunyan образована от прозвища Bugnon - выпуклость, небольшой выступ, шишка. Возможно, она указывает на физический изъян ее первого обладателя [3. С.48].

Черту характера носителя обозначает фамилия Bligh (XII век). Она происходит от древнеанглийского прозвища Blīðә - merry, cheerful (веселый, жизнерадостный) [3. с.34]. От прозвищ происходят фамилии Belcher (красавчик), Cocker (драчун), Colt («жеребенок», резвый и шустрый человек), Armstrong (силач) и многие другие [3].

Наконец, последнее по счету, а не по важности, многие английские фамилии восходят к военному делу. Например, фамилия Alger (alf - эльф, gærspear - копье) появилась в XIII веке [3. с.18]. Фамилия Bacon могла быть 
образована от древнегерманского имени Вассо (означающего to fight, сражаться, воевать, бороться). Она отмечается как фамильное имя с начала нормандского завоевания [3. с.26]. В основе фамилии Уильяма Шекспира «лежит староанглийское прозвище копьеносца, образованное от староанглийского глагола schaken - «shake», трясти, и существительного spere ("spear") копье. Фамилия означает «угрожать копьем». Впервые она упоминалась в XIII веке [3. с.294].

В Великобритании великое множество интересных фамилий. Есть среди них и необычные.

Например, может показаться, что фамилия Bloodworth связана с кровью. Однако это не так. Эта фамилия изначально обозначала жителя города Blidworth в Ноттингемшире, название которого было образовано от староанглийского слова Blīđa, означавшее «счастливый, блаженный» [8]. Fairbairn - красивый ребенок на среднеанглийском и шотландском (bairn = baby) [8]. Фамилия Fear образована от среднеанглийского feare, что означает друг, товарищ [8]. Filtzroy - сын короля. В англо-нормандском французском fils означало сын, а roi - король. Обычно эта фамилия давалась незаконнорожденным детям.

Фамилия Нерburn происходит от названий мест, которые означают «высокий поминальный холм». Ее первым носителем стал печально известный третий муж королевы Марии Шотландской James Hepburn. Другой известной носительницей фамилии стала Одри Хепберн, знаменитая американская актриса [8].

Фамилия Lincoln изначально подчеркивала, что носитель был из английского города Линкольна, который римляне называли Lindum Colonia, что происходило от бретонского lindo (озеро, бассейн) и латинского colonia «колония». Знаменитым носителем был Авраам Лин- кольн (1809-1865), президент Соединенных Штатов во время Гражданской войны [8].

Фамилия Sommer давалась жизнерадостному человеку.

У англичан есть смешные фамилии. Например, Реаcock (павлин). Так зовут английского писателя-романиста (Thomas Love Peacock). Также Braggs (хвастун). Так зовут английских врачей, старшего и младшего брата: (Sir William Henry Braggs и Sir William Lawrence Braggs). Оба они лауреаты Нобелевской премии. Есть смешная и немного неприличная фамилия Butts (мягкое место).

Есть в Великобритании и фамилии, содержащие несуществующие реалии. Например, Griffin, - прозвище по названию мифологического животного с львиной головой и крыльями орла. Изначально оно происходило от греческого 'ҮРИЧ (гриф).

Так что же говорят нам о жителях Великобритании их фамилии?

Во-первых, Великобритания - многокультурная страна с разнообразными диалектами, языками, которые сохранились в фамильных именах. Фамилии хранят древнеанглийский язык, среднеанглийский, шотландский гаэльский, ирландский, валлийский, французский язык.

Во-вторых, выделим основные моменты. Фамилии отражают обычаи и традиции, ремесла и профессии, христианские корни и лингвокреативность британцев.

В целом, британские фамилии, а особенно культурно-значимые британские фамилии, представляют огромный интерес для исследования. Они «наполнены культурной информацией и входят в фоновые знания носителя английского языка ... Фамильные имена репрезентируют англоязычное культурное пространство» [3. с.5].

ЛИТЕРАТУРА

1. Благодатских Николай. Когда на Руси появились фамилии. [Электронный ресурс]. - Режим доступа: zen.yandex.ru > . . . poiavilis-familii-na-Rusi (дата обращения 08.01.21).

2. Валлийские фамилии [Электронный ресурс] - Режим доступа: ru.gaz.wiki/wiki/Welsh_surnames (дата обращения - 12.01.21).

3. Гарагуля С.И. Лингвокультурологический словарь английских фамилий. - М.: ЛЕНАНД, 2018. - 384 с.

4. Ирландские фамилии и их значение (смысловой перевод) //В Ирландии [Электронный ресурс]. - Режим доступа: yandex.ru/turbo/virlandii.ru.

5. Танатарова Орынганым. Как раздавали фамилии русским? [Электронный ресурс]. - Режим доступа: cyrillitsa.ru/past/47134-kak-razdavali-familii-russkim (дата 0бращения 08.01.21).

6. Список шотландских гаэльских фамилий - List of Scottish Gaelic Surnames - gaz.wiki [Электронный ресурс]. - Режим доступа: ru.gaz.wiki//wiki/List_of_ Scottish_Gaelic_surnames (дата обращения 08.01.21).

7. Encyclopedia Britannica (Статья Surname) [Электронный ресурс]. - Режим доступа: www.Britannica.com/topic/surname (дата 0бращения 31.01.21).

8. English Surnames - A list of surnames in which the usage is English [Электронный ресурс]. - Режим доступа: surnamesbehindthename.com (дата обращения 12.01.21). 
9. Livejournal [Электронный ресурс]. - Режим доступа: yandex.ru/turbo/blog.uk.livejournal (дата обращения 08.01.21).

10. The 25 most popular surnames in Britain and what they say about your family history. [Электронный ресурс]. - Режим доступа: www.independent.co.uk/news/ uk (дата обращения 31.01.21).

11. Wikipedia. Noble Families in the United Kingdom [Электронный ресурс]. - Режим доступа: en.m.wikipedia.org/wiki/category-noble-families-of-the-UnitedKingdom (дата обращения 08.01.21).

с Голикова Татьяна Олеговна (tatianagolikova73@yandex.ru).

Журнал «Современная наука: актуальные проблемы теории и практики»

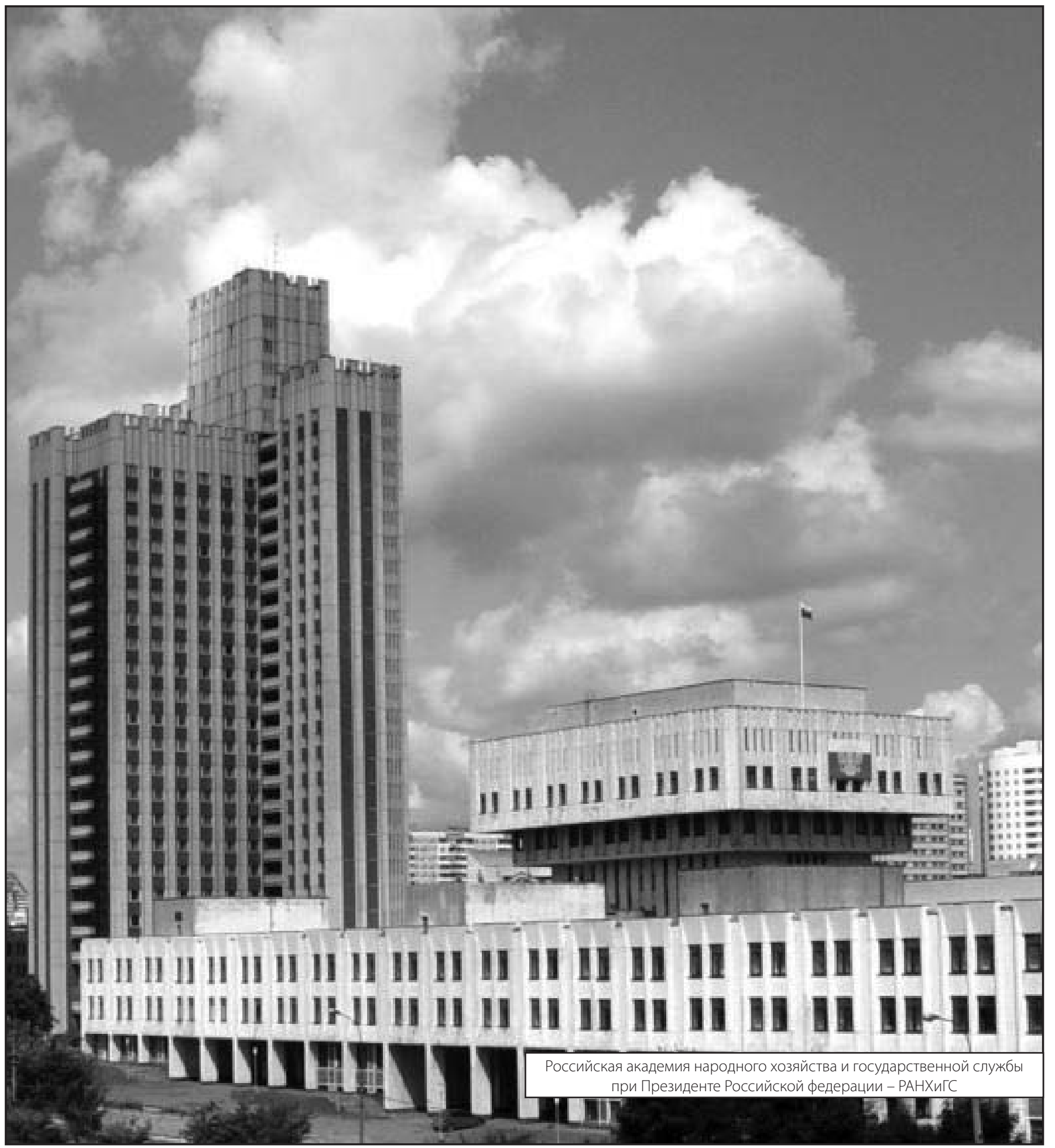

